Nevada

Environmental

Restoration

Project

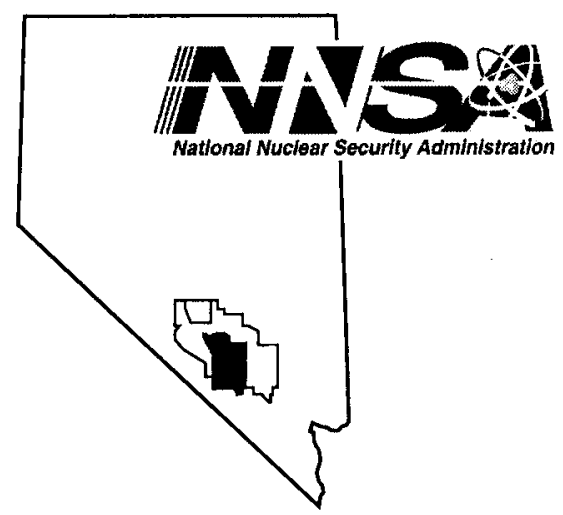

Closure Report For Corrective

Action Unit 390: Areas 9, 10, and 12 Spill Sites, Nevada Test Site, Nevada

Controlled Copy No.:

Revision: 0

October 2005

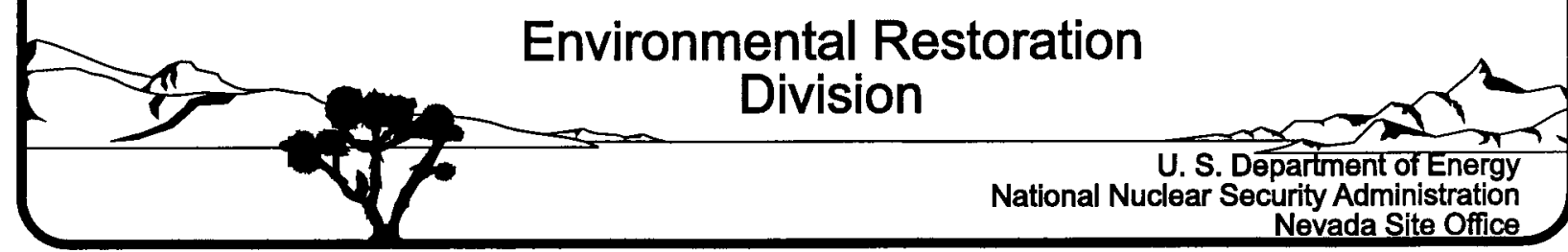




\title{
DISCLAIMER
}

Reference herein to any specific commercial product, process, or service by trade name, trademark, manufacturer, or otherwise, does not necessarily constitute or imply its endorsement, recommendation, or favoring by the United States Government or any agency thereof or its contractors or subcontractors.

This report has been reproduced directly from the best available copy.

Available for sale to the public from:

\author{
U.S. Department of Commerce \\ National Technical Information Service \\ 5285 Port Royal Road \\ Springfield, VA 22161-0002 \\ Telephone: (800) 553-6847 \\ Fax: (703) 605-6900 \\ E-mail: orders@ntis.gov \\ Online ordering: http://www.ntis.gov/ordering.htm
}

Available electronically at http://www.osti.gov/bridge.

Available for a processing fee to the U.S. Department of Energy and its contractors, in paper, from:

U.S. Department of Energy

Office of Scientific and Technical Information

P.O. Box 62

Oak Ridge, TN 37831-0062

Telephone: (865) 576-8401

Fax: (865) 576-5728

E-mail: reports@adonis.osti.gov 


\title{
CLOSURE REPORT FOR CORRECTIVE ACTION UNIT 390: AREAS 9, 10, AND 12 SPILL SITES, NEVADA TEST SITE, NEVADA
}

\author{
U.S. Department of Energy \\ National Nuclear Security Administration \\ Nevada Site Office \\ Las Vegas, Nevada
}

Controlled Copy No:

Revision: 0

October 2005 
THIS PAGE INTENTIONALLY LEFT BLANK 


\section{CLOSURE REPORT FOR CORRECTIVE ACTION UNIT 390: AREAS 9, 10, AND 12 SPILL SITES, NEVADA TEST SITE, NEVADA}

Approved By: $\frac{\text { SIGNATURE APPROVED }}{\begin{array}{l}\text { Kevin Cabble, Acting Project Manager } \\ \text { Industrial Sites Project }\end{array}}$

Approved By: $\frac{\text { SIGNATURE APPROVED }}{\text { JanetAppenzeller- }}$ Environmental Restoration Division
Date: $10.13 \cdot 05$

Date: $10 / 13 / 05$ 
THIS PAGE INTENTIONALLY LEFT BLANK 


\section{TABLE OF CONTENTS}

ACRONYMS AND ABBREVIATIONS ................................................................... vii

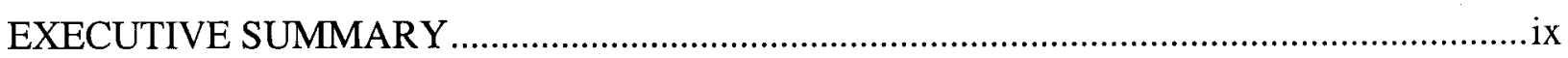

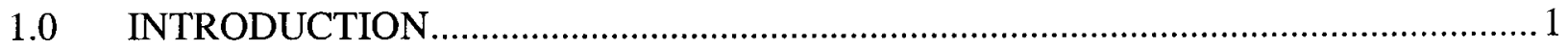

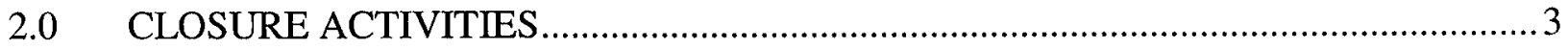

2.1 DESCRIPTION OF CLOSURE ACTIVITIES ...................................................... 3

2.1.1 Preplanning and Site Preparation.................................................... 3

2.2 WASTE CLASSIFICATION ACTIVITIES ......................................................... 3

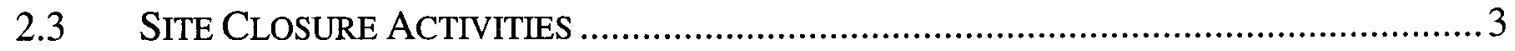

2.3.1 CAS 09-99-03: Wax, Paraffin .......................................................... 3

2.4 Site Closure ACtIVITIES ............................. ERror! BOOKMARK NOT DEFINED.

2.4.1 CAS 09-99-03: Wax, Paraffin ............... Error! Bookmark not defined.

2.4.2 CAS 10-99-01: Epoxy Tar Spill ....................................................... 4

2.4.3 CAS 10-99-03: Tar Spills ............................................................ 4

2.4.4 CAS 12-25-03: Oil Stains (2); Container ............................................ 4

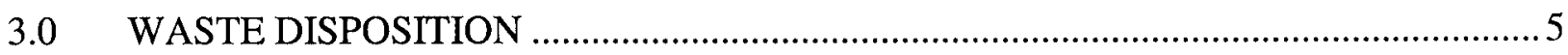

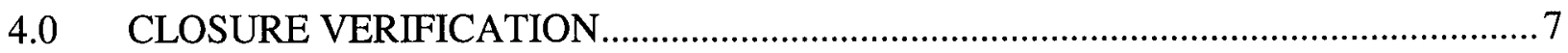

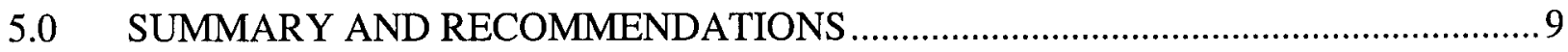

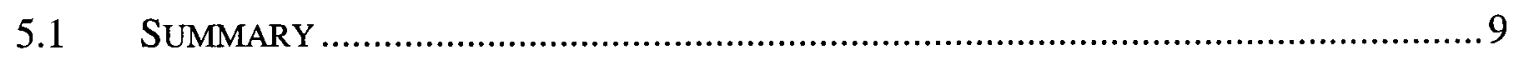

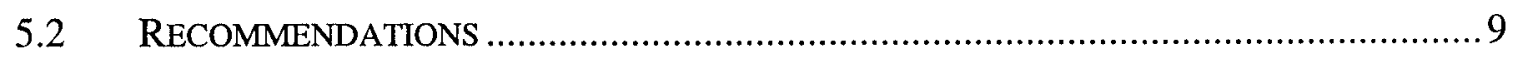

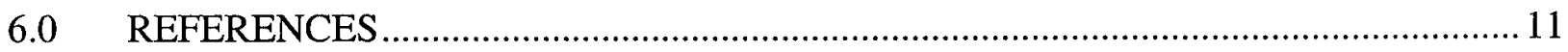

\section{FIGURES}

Figure 1. CAU 390 Site Location MAP

\section{TABLES}

TABle 1. Summary of ANALytical Results for WASte Classification SAMPLES................ 4 


\section{TABLE OF CONTENTS (continued)}

\section{APPENDICES}

APPENDIX A: WASTE CLASSIFICATION SAMPLE ANALYTICAL RESULTS .............A-1 APPENDIX B: SECTORED HOUSEKEEPING SITE CLOSURE VERIFICATION FORMS ................................................................ B-1

APPENDIX C: NATIONAL ENVIRONMENTAL POLICY ACT ENVIONMENTAL EVALUATION CHECKLIST C-1

APPENDIX D: FFACO CORRESPONDENCE D-1 LIBRARY DISTRIBUTION LIST 


\section{ACRONYMS AND ABBREVIATIONS}

$\begin{array}{ll}\text { BN } & \text { Bechtel Nevada } \\ \text { CAS } & \text { Corrective Action Site } \\ \text { CAU } & \text { Corrective Action Unit } \\ \mathrm{ft} & \text { foot (feet) } \\ \mathrm{ft}^{3} & \text { cubic foot (feet) } \\ \text { FFACO } & \text { Federal Facility Agreement and Consent Order } \\ \text { mg/L } & \text { milligram(s) per liter } \\ \text { NDEP } & \text { Nevada Division of Environmental Protection } \\ \text { ND } & \text { not detected } \\ \text { NNSA/NSO } & \begin{array}{l}\text { U.S. Department of Energy, National Nuclear Security Administration } \\ \text { Nevada Site Office }\end{array} \\ \text { NCLP } & \text { Nevada Test Site } \\ \text { RCRA } & \text { Resource Conservation and Recovery Act } \\ & \text { cubic yard(s) } \\ & \end{array}$


Closure Report - CAU 390

Section: Acronyms \& Abbr.

Revision: 0

Date: October 2005

\section{THIS PAGE INTENTIONALLY LEFT BLANK}




\section{EXECUTIVE SUMMARY}

Corrective Action Unit (CAU) 390 consists four Corrective Action Sites (CASs) located in Areas 9, 10, and 12 of the Nevada Test Site. The closure activities performed at the CASs include:

- CAS 09-99-03, Wax, Paraffin: 2 cubic yards of drilling polymer was removed on June 20, 2005, and transported to the Area 9 U10c Landfill for disposal.

- CAS 10-99-01, Epoxy Tar Spill: 2 cubic feet of asphalt waste was removed on June 20, 2005, and transported to the Area 9 U10c Landfill for disposal.

- CAS 10-99-03, Tar Spills: 3 cubic yards of deteriorated asphalt waste was removed on June 20, 2005, and transported to the Area 9 U10c Landfill for disposal.

- CAS 12-25-03, Oil Stains (2); Container: Approximately 16 ounces of used oil were removed from ventilation equipment on June 28,2005 , and recycled.

One CAS 10-22-19, Drums, Stains, was originally part of CAU 390 but was transferred out of CAU 390 and into CAU 550, Drums, Batteries, and Lead Materials. The transfer was approved by the Nevada Division of Environmental Protection on August 19, 2005, and a copy of the approval letter is included in Appendix D of this report. 
Closure Report - CAU 390

Section: Executive Summary

Revision: 0

Date: October 2005

\section{THIS PAGE INTENTIONALLY LEFT BLANK}




\subsection{INTRODUCTION}

This report documents that the closure activities conducted for Corrective Action Unit (CAU) 390: Areas 9, 10, and 12 Spill Sites, met the approved closure standards. CAU 390 is listed in Appendix III of the Federal Facility Agreement and Consent Order (FFACO, 1996) and consists of four Corrective Action Sites (CAS) located in Area 9, 10, and 12 of the Nevada Test Site (NTS) (Figure 1):

- CAS 09-99-03 Wax, Paraffin

- CAS 10-99-01 Epoxy Tar Spill

- CAS 10-99-03 Tar Spills

- CAS 12-25-03 Oil Stains (2); Container

Closure activities at the above CASs consisted of documenting current site conditions, identifying and removing debris and other material, classifying and disposing of any generated waste, and verifying by visual inspection that each site was clean of housekeeping debris.

Copies of the analytical results for the waste classification samples are included in Appendix A. Copies of the "Sectored Housekeeping Site Closure Verification Form" for each CAS are included in Appendix B. A copy of the "National Environmental Policy Act Evaluation Checklist" for the housekeeping CAUs is included in Appendix C. Appendix D includes copies of applicable FFACO correspondence.

CAS 10-22-19, Drums, Stains, was originally part of CAU 390 but was transferred out of CAU 390 and into CAU 550, Drums, Batteries, and Lead Materials. The transfer was approved by the Nevada Division of Environmental Protection on August 19, 2005, and a copy of the approval letter is included in Appendix D of this report. 


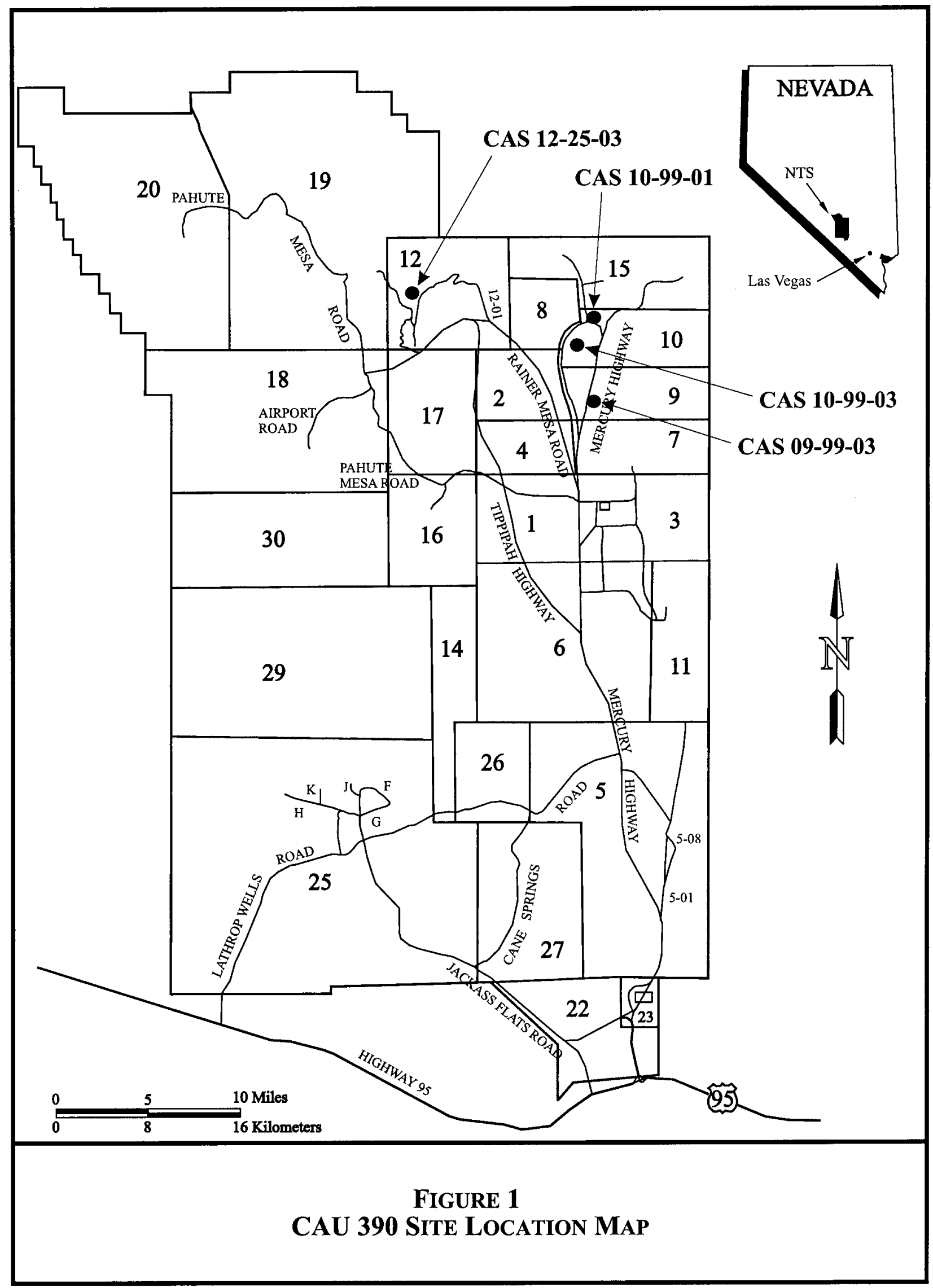




\subsection{CLOSURE ACTIVITIES}

This section details the specific closure activities completed for CAU 390: Areas 9, 10, and 12 Spill Sites.

\subsection{DESCRIPTION OF Closure ACTIVITIES}

\subsubsection{Preplanning and Site Preparation}

Planning documents prepared prior to the beginning of closure activities include the following:

- Sectored Clean-up Work Plan For Housekeeping Category Waste Sites (U.S. Department of Energy, National Nuclear Security Administration Nevada Site Office [NNSA/NSO], 2003).

- Generic Field Management Plan for Housekeeping Category Waste Sites (NNSA/NSO, 2005).

- Site-Specific Health and Safety Plan for Corrective Action Units 167, 210, 390, 390, and 395 Housekeeping Sites, (Bechtel Nevada [BN], 2005).

- BN Solid Waste Operations Work Packages.

- NNSA/NSO Real Estate/Operation Permit.

\subsection{Waste Classification Activities}

Waste generated at CAS 09-99-03 was identified as drilling polymer. To verify that the waste met the Area 9 U10c Landfill disposal requirements, two waste classification samples of the material were collected on May 18, 2005 and submitted to an off-site laboratory for total Resource Conservation Recovery Act (RCRA) metals analysis. Analytical results verified that the waste was not hazardous for Resource RCRA metals. Table 1 summarizes the RCRA Toxicity Characteristic Leaching Procedure (TCLP) metal results. The reported values are calculated from results for total RCRA metals by dividing each total metal result by 20 to give a maximum leachable concentration in milligrams per liter $(\mathrm{mg} / \mathrm{L})$. The calculated TCLP metal results are well below RCRA levels for hazardous waste. Copies of the analytical results for total RCRA metals for the waste classification samples are included in Appendix A.

\subsection{Site Closure Activities}

Appendix B includes a copy of the "Sectored Housekeeping Site Closure Verification Form," including site information and before-and-after site photographs, for each closed CAS.

\subsubsection{CAS 09-99-03: Wax, Paraffin}

On June 20, 2005, the pile of drilling polymer was removed from the site and transported to Area $9 \mathrm{U} 10 \mathrm{c}$ Landfill for disposal. A total of 2 cubic yards $\left(\mathrm{yd}^{3}\right)$ of material was removed from the site. No further action is required at this site. 
Table 1. Summary of ANalytical Results for Waste Classification Samples

\begin{tabular}{|c|c|c|c|c|c|c|c|c|}
\hline \multirow[b]{2}{*}{ SAMPLE } & \multicolumn{8}{|c|}{ CALCULATED TCLP CONCENTRATION (mg/L) } \\
\hline & $\frac{\frac{y}{z}}{\frac{2}{4}}$ & 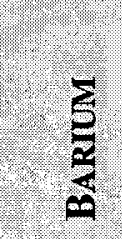 & $\frac{\sum}{\text { Ej }}$ & 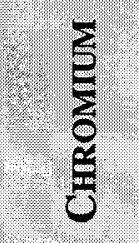 & 趈 & 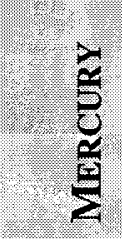 & 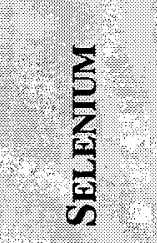 & $\frac{a}{\frac{\pi}{a}}$ \\
\hline RCRA Levels & 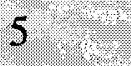 & 100 & 1 & 5 & 5 & 0.2 & 1 & 5 \\
\hline 099903-1 & 0.02 & 0.03 & ND & 0.6 & 0.04 & ND & 0.06 & $\mathrm{ND}$ \\
\hline $\begin{array}{c}\text { Dup A } \\
\text { (Duplicate of } \\
\text { 099903-1) }\end{array}$ & 0.04 & 0.03 & ND & 0.05 & 0.04 & ND & 0.05 & $\mathrm{ND}$ \\
\hline
\end{tabular}

$\mathrm{mg} / \mathrm{L}=$ milligrams per liter

RCRA = Resource Conservation and Recovery Act

TCLP $=$ Toxicity Characteristic Leaching Procedure

$\mathrm{ND}=$ not detected at concentrations above the analytical method detection limit.

\subsubsection{CAS 10-99-01: Epoxy Tar Spill}

On June 20,2005 , less than 2 cubic feet $\left(\mathrm{ft}^{3}\right)$ of deteriorated asphalt was removed from around the plugged drill casing and transported to the Area 9 U10c Landfill for disposal. No further action is required at this site.

\subsubsection{CAS 10-99-03: Tar Spills}

On June 20, 2005, approximately $3 \mathrm{yd}^{3}$ of deteriorated asphalt was removed from the site and transported to the Area $9 \mathrm{U} 10 \mathrm{c}$ Landfill for disposal. No further action is required at this site.

\subsubsection{CAS 12-25-03: Oil Stains (2); Container}

On June 28,2005 , approximately 16 fluid ounces of used oil was drained from the glass reservoirs on the equipment and transported to BN Fleet Services for recycling. No further action is required at this site. 


\subsection{WASTE DISPOSITION}

Waste generated during the closure of CAU 390 was disposed as follows:

- CAS 09-99-03, Wax, Paraffin: $2 \mathrm{yds}^{3}$ of drilling polymer was taken to Area 9 U10c Landfill.

- CAS 10-99-01, Epoxy Tar Spill: $2 \mathrm{ft}^{3}$ of asphalt was taken to Area 9 U10c Landfill.

- CAS 10-99-03, Tar Spills: $3 \mathrm{yds}^{3}$ of deteriorated asphalt was taken to Area 9 U10c Landfill.

- CAS 12-25-03, Oil Stains (2); Container: Approximately 16 fluid ounces of used oil removed from ventilation equipment was recycled. 
Closure Report - CAU 390

Section: Waste Disposition

Revision: 0

Date: October 2005

\section{THIS PAGE INTENTIONALLY LEFT BLANK}




\subsection{CLOSURE VERIFICATION}

None of the CASs required soil verification sampling. Closure verification was performed by field observation and photo-documenting current site conditions. A copy of the Sectored Housekeeping Site Closure Verification Form for each closed CAS is included in Appendix A. 
Closure Report - CAU 390

Section: Closure Verification

Revision: 0

Date: October 2005

\section{THIS PAGE INTENTIONALLY LEFT BLANK}




\subsection{SUMMARY AND RECOMMENDATIONS}

\subsection{SUMMARY}

The following closure activities were completed at the CASs in CAU 390:

- CAS 09-99-03, Wax, Paraffin: Clean-closed by disposal of $2 \mathrm{yds}^{3}$ of drilling polymer at U10c Landfill. No further action necessary.

- CAS 10-99-01, Epoxy Tar Spill: Clean-closed by disposal of $2 \mathrm{ft}^{3}$ of deteriorated asphalt at U10c Landfill. No further action necessary.

- CAS 10-99-03, Tar Spills: Clean-closed by disposal of $3 \mathrm{yds}^{3}$ of deteriorated asphalt at U10c Landfill. No further action necessary.

- CAS 12-25-03, Oil Stains (2); Container: Clean-closed by removal and recycling of approximately 16 fluid ounces of used oil at BN Fleet Services. No further action necessary.

\subsection{RECOMMENDATIONS}

Because closure activities for CAU 390 have been completed following the Nevada Division of Environmental Protection (NDEP)-approved Sectored Clean-up Work Plan for Housekeeping Category Waste Sites (NNSA/NSO, 2003) as documented in this report, NNSA/NSO requests the following:

1. NDEP provide a "Notice of Completion" to the NNSA/NSO for the closure of CAU 390.

2. CAU 390 be transferred from Appendix III to Appendix IV of the FFACO Closed Corrective Action Units (FFACO, 1996). 
Closure Report - CAU 390

Section: Summary \& Recomm.

Revision: 0

Date: October 2005

THIS PAGE INTENTIONALLY LEFT BLANK 


\subsection{REFERENCES}

BN, see Bechtel Nevada.

Bechtel Nevada. 2005. Site-Specific Health and Safety Plan for Corrective Action Sites 167, 210,390,390, and 395, Nevada Test Site, Nevada, Rev. 1. Las Vegas, NV.

FFACO, see Federal Facility Agreement and Consent Order.

Federal Facility Agreement and Consent Order. 1996 (as amended). Agreed to by the State of Nevada, U.S. Department of Energy, and U.S. Department of Defense.

NNSA/NSO, see U.S. Department of Energy, National Nuclear Security Administration Nevada Site Office.

U.S. Department of Energy, National Nuclear Security Administration Nevada Site Office. 2005. Generic Field Management Plan for Housekeeping Category Waste Sites, Revision 2, Las Vegas, NV.

U.S. Department of Energy, National Nuclear Security Administration Nevada Site Office. 2003. Sectored Clean-up Work Plan for Housekeeping Category Waste Sites, DOE/NV--579-REV-3. Las Vegas, NV. 
Closure Report - CAU 390

Section: References

Revision: 0

Date: October 2005

THIS PAGE INTENTIONALLY LEFT BLANK 
Date: October 2005

\section{APPENDIX A}

\section{WASTE CLASSIFICATION SAMPLE ANALYTICAL RESULTS}


Closure Report - CAU 390

Section: Appendix A

Revision: 0

Date: October 2005

THIS PAGE INTENTIONALLY LEFT BLANK 


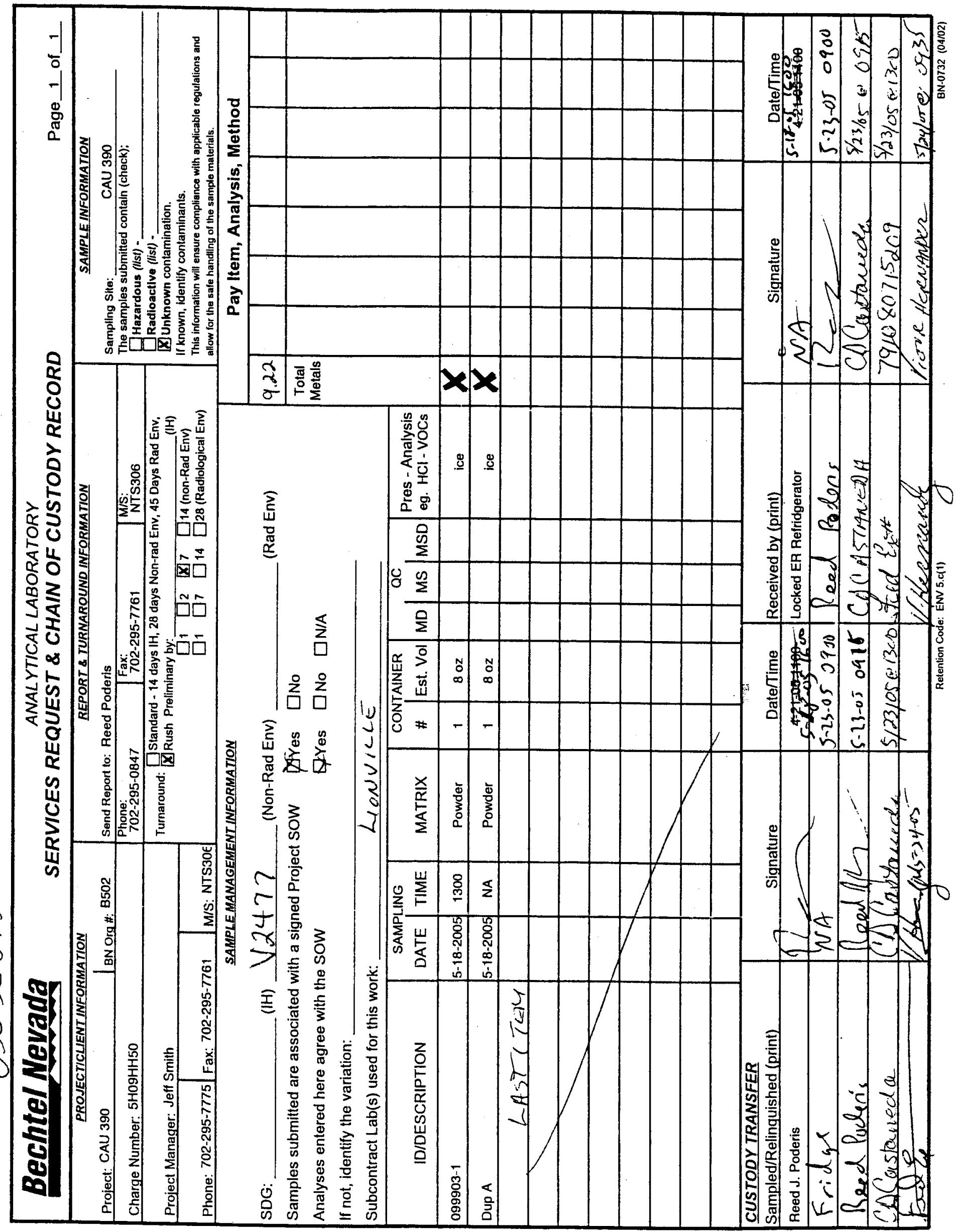




\section{$9 / V L I$}

\section{Analytical-Report}

Client : BECHTEL NEVADA V2477

LVL\# : 0505L575
W.O.\# : 60052-001-001-0001-00

Date Received : 05-24-05

\section{SW846 METALS}

1. This narrative covers the analyses of 2 solid samples.

2. The samples were prepared and analyzed in accordance with $\underline{\text { SW-846 }}$ protocol and reported with a CLP deliverable.

3. ICVs, CCVs, and LCSs stock standards were purchased from Inorganic Ventures Laboratory and High Purity.

4. All analyses were performed within the required holding times.

5. All results presented in this report are derived from samples that met LvLI's sample acceptance policy.

6. All Initial and Continuing Calibration Verifications (ICV/CCVs) were within control limits.

7. All Initial and Continuing Calibration Blanks (ICB/CCBs) were within method criteria.

8. All preparation/method blanks were within method criteria. Refer to form 3.

9. All ICP Interference Check Standards were within control limits. Refer to form 4.

10. All laboratory control samples (LCS) were within the $80-120 \%$ control limits. Refer to form 7.

11. All serial dilution percent differences were within $\underline{\text { SW-846 }}$ control limits. Refer to form 9 .

12. All matrix spike (MS) and matrix spike duplicate (MSD) recoveries were within the $75-125 \%$ control limits. Refer to form $5 \mathrm{~A}$.

13. The duplicate analysis for 1 analyte was outside the $20 \%$ Relative Percent Difference (RPD) control limits. Refer to form 6. 
14. All sample IDs were changed to accommodate the EPA naming convention which allows a maximum of 6 characters on all CLP Forms. Refer to the comments section of form 1 for the original ID.

15. LVLI is NELAP accredited by the state of Pennsylvania and holds over 20 additional state accreditations. For a complete listing of accrediting authorities and the corresponding analytes/methods, please contact your Project Manager.
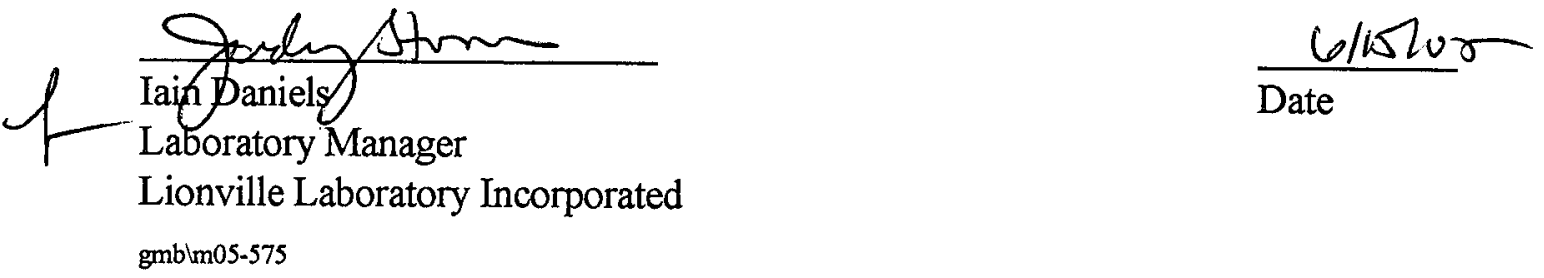

Lionville Laboratory Incorporated

gmblm05-575 
EPA SAMPLE NO.

099903

Lab Name: LIONVILLE_LABORATORY

Lab Code: LVLI

Matrix (soil/water): SOIL_

$\begin{array}{ll}\text { Level (low/med) : } & \text { LOW }- \\ \% \text { Solids: } & 100 \overline{0}\end{array}$

Contract: 60052

SAS No.:

SDG NO.: DUP1

Lab Sample ID: 0505L575-001

Date Received: 05/24/05

Concentration Units (ug/L or $\mathrm{mg} / \mathrm{kg}$ dry weight): MG/KG

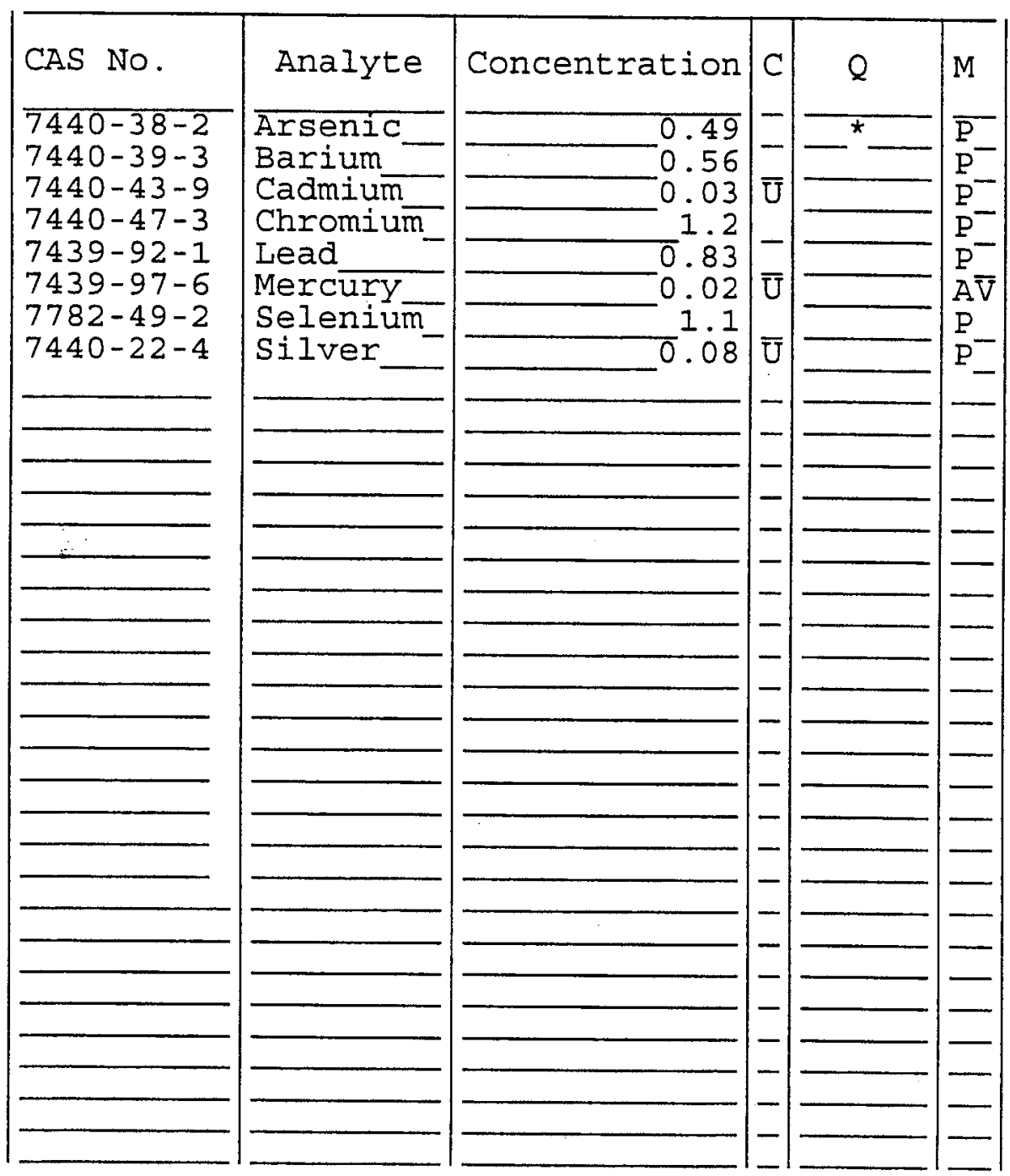

Color Before:

Color After:

Comments :

099903-1
Clarity Before:

Clarity After:
Texture:

Artifacts : 
U.S. EPA

1

INORGANIC ANALYSES DATA SHEET
Jab Name: LIONVILLE_LABORATORY jab Code: LVLI Jatrix (soil/water): SoIL jevel (low/med):

bolids :
Contract: 60052

SAS NO.:

Lab Sample ID: 0505L575-002

Date Received: 05/24/05

Concentration Units (ug/L or $\mathrm{mg} / \mathrm{kg}$ dry weight): MG/KG

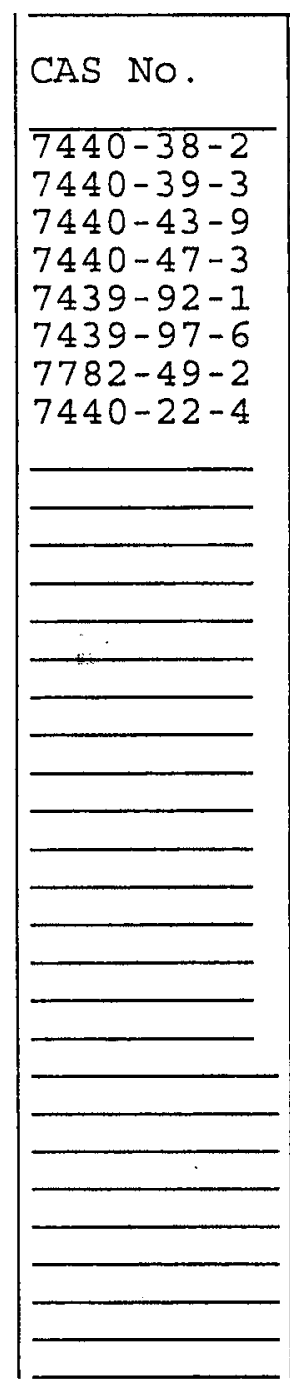

Color Before: Color After:

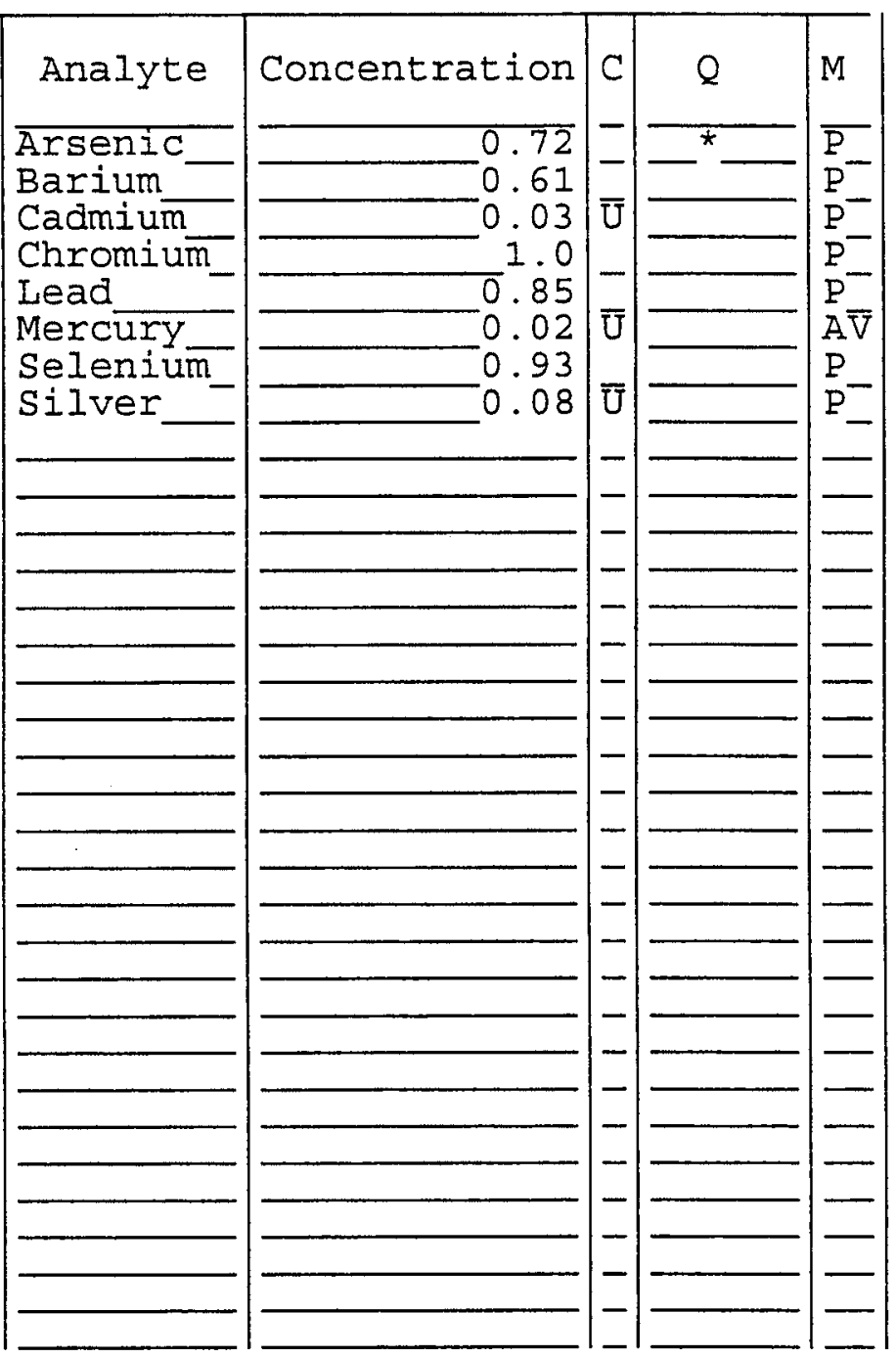

Clarity Before: Clarity After:
Texture: Artifacts :

\section{Comments :} DUPA 


\section{APPENDIX B}

\section{SECTORED HOUSEKEEPING SITE CLOSURE VERIFICATION FORMS}


Closure Report - CAU 390

Section: Appendix B

Revision: 0

Date: October 2005

\section{THIS PAGE INTENTIONALLY LEFT BLANK}

B-2 


\section{Sectored Housekeeping Site Closure Verification Form}

Closure Verification Date: $06 / 20 / 2005$

CAU Number: 390

CAS Number: 09-99-03

CAS Description: Wax, Paraffin

Sector Designation: NTS Sector F

Housekeeping Site General Location: U-9av Crater

Elevation: 1,285 meters

Northing: 4,109,412m (UTM Zone 11)

Latitude: 37.12715

Easting: 585,594 m (UTM Zone 11)

Longitude: -116.03642

Coordinate/Elevation Data Obtained from: North American Datum, 1983.

Site Access Route: Mercury Highway north to Rainier Mesa Road. Turn left (northwest) on Rainier Mesa Road and proceed to 2-03 Road. Turn right (north) on 2-03 Road and proceed 0.5 mile to 9-01 Road. Turn right (east) on 9-01 Road and proceed approximately 2.11 miles to Old Mercury Highway. Turn left (north) on Old Mercury Highway and proceed 0.4 mile to 9V Road. Turn right (east) on 9V Road and proceed 0.2 mile to the U-9av Crater on the right (south). The site is located south of 9V Road and $80 \mathrm{ft}$ northeast of the U-9av Crater.

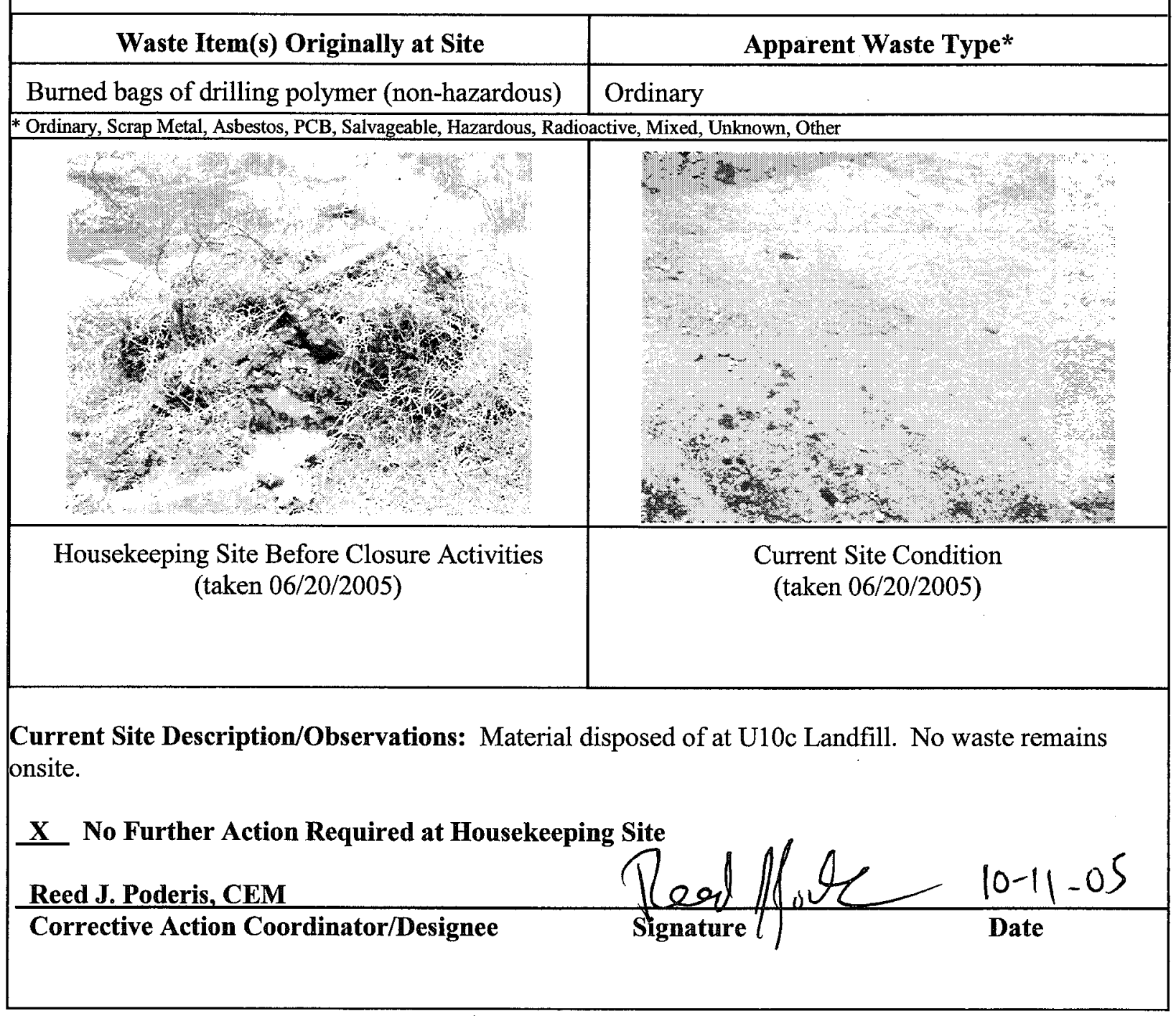




\section{Sectored Housekeeping Site Closure Verification Form}

Closure Verification Date: 06/20/2005

CAU Number: 390

CAS Number: 10-99-01

CAS Description: Epoxy Tar Spill

Sector Designation: NTS Sector F

Housekeeping Site General Location: U-10bf Crater

Elevation: 1,339 meters

Northing: 4,116,544 m (UTM Zone 11) Easting: 584,445 m (UTM Zone 11)

Latitude: 37.19154

Longitude: -116.04854 .

Coordinate/Elevation Data Obtained from: North American Datum, 1983.

Site Access Route: Mercury Highway north to Rainier Mesa Road. Turn left (northwest) on Rainier Mesa Road and proceed to 2-03 Road. Turn right (north) on 2-03 Road and proceed north/northeast to 2-05 Road and then to Circle Road. Turn left (north) onto Circle Road and proceed northeast to 10-02 Road. Turn left (north) on 10-02 Road and proceed 0.5 mile to a faint dirt road. Turn left (west) onto the dirt road and proceed to the mud pit. The site is approximately $600 \mathrm{ft}$ north of $\mathrm{U}-10 \mathrm{bf}$.

\begin{tabular}{|l|l|}
\hline \multicolumn{1}{|c|}{ Waste Item(s) Originally at Site } & \multicolumn{1}{|c|}{ Apparent Waste Type* } \\
\hline Loose asphalt pieces. & Ordinary \\
\hline * Ordinary, Scrap Metal, Asbestos, PCB, Salvageable, Hazardous, Radioactive, Mixed, Unknown, Other \\
\hline \\
\hline
\end{tabular}




\section{Sectored Housekeeping Site Closure Verification Form}

Closure Verification Date: 06/20/2005

CAU Number: 390

CAS Number: $10-99-03$

CAS Description: Tar Spills

Sector Designation: NTS Sector F

Housekeeping Site General Location: U-10am \#5 Crater

Elevation: 1,343 meters

Northing: 4,114,178 m (UTM Zone 11) Easting: $581,856 \mathrm{~m}$ (UTM Zone 11)

Latitude: 37.17044

Longitude: -116.07797

Coordinate/Elevation Data Obtained from: North American Datum, 1983.

Site Access Route: Mercury Highway north to Rainier Mesa Road. Turn left (northwest) on Rainier Mesa Road and proceed to 2-07 Road. Turn right (east) on 2-07 Road and proceed approximately 1.4 miles to a dirt road on the left (north). Turn left (north) on the dirt road and continue 0.4 mile. The stain areas are located 10-50 ft west of the dirt road.

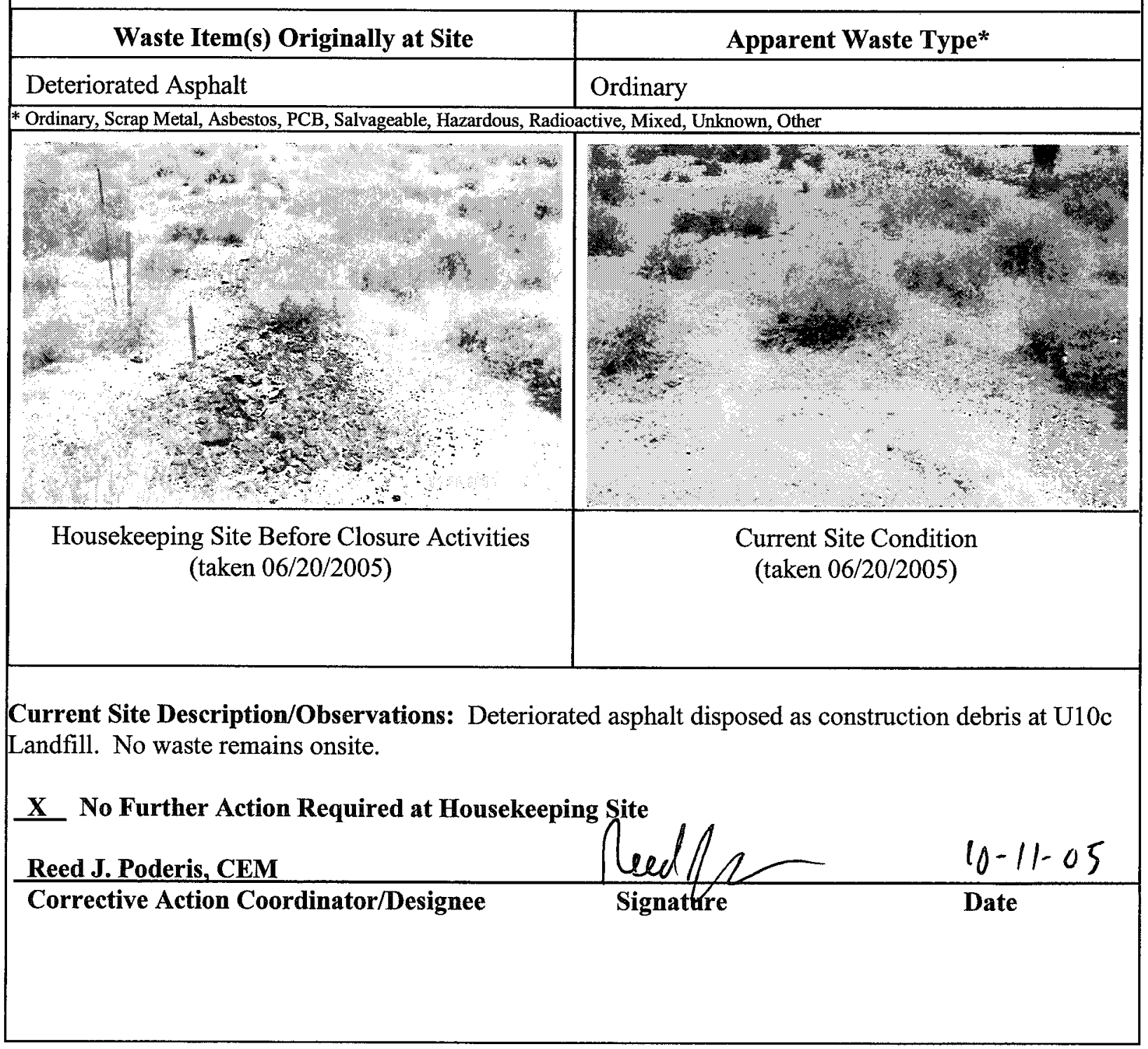




\section{Sectored Housekeeping Site Closure Verification Form}

Closure Verification Date: 06/28/2005

CAU Number: 390

CAS Number: $12-25-03$

CAS Description: Oil Stains (2); Container

Sector Designation: NTS Sector F

Housekeeping Site General Location: U-12n. 10 Vent Hole

Elevation: 2,217 meters

Northing: 4,118,210 m (UTM Zone 11) Easting: $570,409 \mathrm{~m}$ (UTM Zone 11)

Latitude: 37.20772

Longitude: -116.20651

Coordinate/Elevation Data Obtained from: North American Datum, 1983.

Site Access Route: Mercury Highway north to Rainier Mesa Road. Turn left (northwest) on Rainier Mesa Road and proceed past the Area 12 Camp. Continue on Rainier Mesa Road until it becomes Stockade Wash Road. Proceed on Stockade Wash Road to "R" Road. Turn right (southwest) onto "R" Road (South Rainier Mesa Road). Turn left (west) onto "T" Road and proceed to "H" Road. Turn right (east) on "H" Road and proceed 1.4 miles to a fork in the road. Turn right (south) and proceed approximately 0.1 mile to the end of the road.

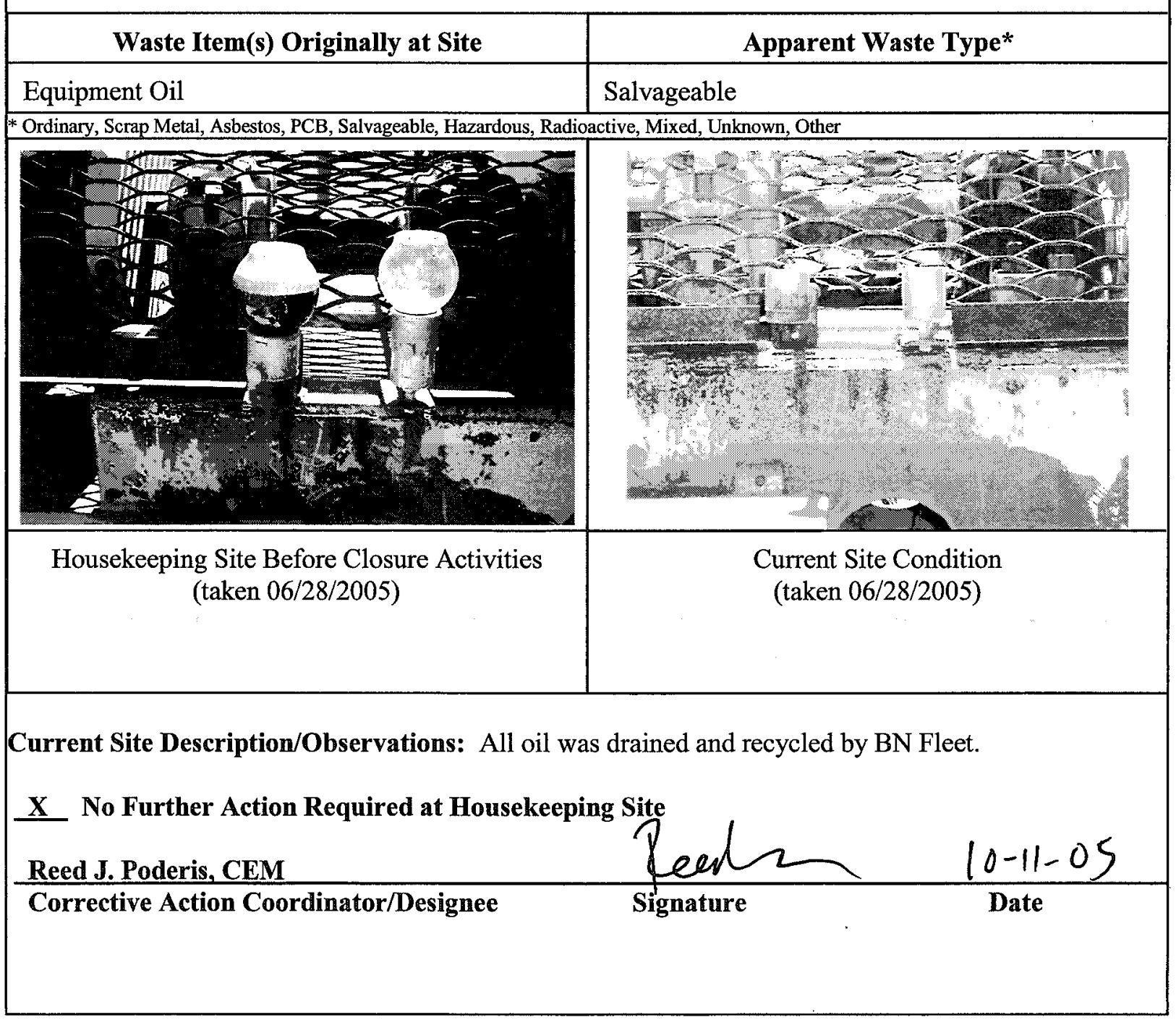




\section{APPENDIX C:}

\section{NATIONAL ENVIRONMENTAL POLICY ACT ENVIRONMENTAL EVALUATION CHECKLIST}


Closure Report - CAU 390

Section: Appendix C

Revision: 0

Date: October 2005

\section{THIS PAGE INTENTIONALLY LEFT BLANK}

C-2 


\section{U.S. DEPARTMENT OF ENERGY \\ NATIONAL NUCLEAR SECURITY ADMINISTRATION NEVADA SITE OFFICE NEPA ENVIRONMENTAL EVALUATION CHECKLIST}

\begin{tabular}{|l|l|}
\hline \multicolumn{1}{|c|}{ FOLLOW ATTACHED PROCEDURES FOR COMPLETING CHECKLIST } \\
$\begin{array}{l}\text { A. Project/Activity Title (Attach a brief description of proposed project) } \\
\text { Housekeeping Sites Closure/Cleanup Activities (CAUs 286, 390, 395) }\end{array}$ & $\begin{array}{l}\text { Date } \\
\mathbf{0 4 / 2 6 / 2 0 0 5}\end{array}$ \\
\cline { 2 - 3 } $\begin{array}{l}\text { Project Location } \\
\text { NTS, Various Areas }\end{array}$ & Proposed By (if other than NNSANSO) \\
\hline $\begin{array}{l}\text { NNSANSO Line Management Organization } \\
\text { Environmental Restoration }\end{array}$ & $\begin{array}{l}\text { NNSA/NSO Project/Program Manager } \\
\text { Sabine Curtis }\end{array}$ \\
\hline
\end{tabular}

ENVIRONMENTAL CONSIDERATIONS: If any phase of the project/activity involves any of the following considerations, check yes and explain in project description. See NV-16A for consideration quidelines and examples.

\begin{tabular}{|c|c|c|c|c|c|c|c|}
\hline CONSIDERATION & YES & NO & UNK & CONSIDERATION & YES & NO & UNK \\
\hline WASTE & & & & AIR EMISSIONS & & & \\
\hline 1 Non-Rad Solid Waste & $\mathbf{x}$ & & & 1 Biological MateriaVChemical Release & & $\mathbf{x}$ & \\
\hline 2 Hazardous Waste & $x$ & & & 2 Dust/Particulate Matter & $\mathbf{x}$ & & \\
\hline 3 Low-level Rad Waste & $\bar{x}$ & & & 3 Explosives & ? & $\mathbf{x}$ & \\
\hline 4 Mixed Waste & $\bar{x}$ & & & 4 Diesel Generators & & $\bar{x}$ & \\
\hline 5 TRU/Mixed TRU Waste & & $\mathbf{x}$ & & 5 Open Buming & & $\bar{x}$ & \\
\hline \multirow[t]{2}{*}{6 Wastewater (domestic/ndustrial) } & & $\bar{x}$ & & & & & \\
\hline & & & & STTE LOCATIONOTHER & & & \\
\hline HAZARDOUS MATERIALS & & & & 1 Environmental Restoration Site (CAU) & $\mathbf{x}$ & & \\
\hline 1 Petroleum/Fuel (storage/use) & $\mathbf{x}$ & & & 2 Excavation/Land Surface Disturbance & $x$ & & \\
\hline 2 Underground Storage Tanks & & $\mathbf{x}$ & & 3 Off road travel & & $x$ & \\
\hline 3 Aboveground Storage Tanks & & $\mathbf{x}$ & & 4 BiologicaVTortoise Resource Area & & $\bar{x}$ & \\
\hline 4 PCB's/Asbestos & & $\mathbf{x}$ & & 5 Cultura//Historic Resource Area & & $\bar{x}$ & \\
\hline 5 Pesticides/Herbicides & & $\bar{x}$ & & 6 Change in Existing Drainage Pattem & & $\mathbf{x}$ & \\
\hline 6 Radioactive Materials & & $\mathbf{x}$ & & 7 Impact to Environmental Monitoring System & & $x$ & \\
\hline 7 Biological Materials/Simulants & & $x$ & & 8 Unexploded Ordnance Area & & $\mathbf{x}$ & \\
\hline 8 Beryllium & & & $\mathbf{x}$ & 9 Noise & $\mathbf{x}$ & & \\
\hline 9 Chemical storage/use & & $\bar{x}$ & & 10 Radiation controlled area & $\mathbf{x}$ & & \\
\hline 10 Use of explosives/firearms & & $\bar{x}$ & & 11 Drinking water system involvement & & $\mathbf{x}$ & \\
\hline
\end{tabular}

FrF

B. Is the project/activity included in the final NTS EIS and the ROD or other NEPA document?
Yes
$\mathrm{x}$
(complete Sections C, D, and E)
No
(complete Sections D, E, and F)

C. This project/activity is included in the NTS EIS/ROD (or other NEPA document) under the following section and page no.: NTS EIS Volume 1, Appendix A, A.3.1.3 - Environmental Restoration Program; Industrial Sites Project

D. Does the proposed project/activity require any local, state, or federal permits or notifications? $\quad$ Yes $\mathbf{X}$ No

E. If, based on the project description and the prellminary environmental considerations noted above, the proposed action fits within a class of action listed in Subpart D of 10 CFR 1021, write in the space below, the paragraph number and short title from the appropriate table of contents of Subpart D, Appendix B, C, or D, for a CX, EA, or EIS. If the proposed action does not fit within any class of action, write "Not Listed" betow.

\section{F. NEPA COMPLIANCE OFFICER DETERMINATION OR RECOMMENDATION:}

I have determined that the proposed activity as described in item $A$ above, has been adequately addressed in the document cited in item $\mathrm{C}$ for the purpose of NEPA. No further analysis or documentation is required pursuant to NEPA.

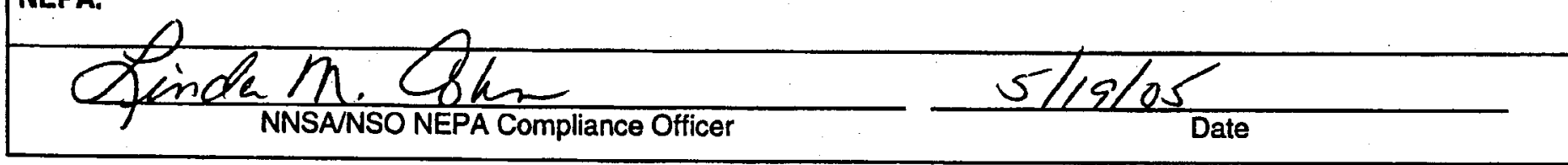




\section{CAUs 286, 390, \& 395 Housekeeping Sites Closure/Cleanup Activities}

\section{Project Description}

The purpose of this project is to remove various debris located at several Corrective Action Units (CAUs). The CAUs are housekeeping sites, located at the Nevada Test Site (NTS). CAU 286 is located in Areas 1, 2, 3, 4, 6, 10, and 18 and consists of twelve CASs. CAU 390 is located in Areas 9, 10, and 12 and consists of six CASs. CAU 395 is located in Area 19 and consists of ten CASs. A detailed list of the CASs and description of the CASs and descriptions is provided in the Federal Facility Agreement and Consent Order (FFACO) of 1996. Each CAU is listed below, with a brief description of the types of debris present in the CASs.

CAU 286 includes pieces of lead shielding in various locations. A pile of concrete is also included. Some of the waste may be radioactive. The lead material is hazardous. However, the majority of the lead material is salvageable for recycling.

CAU 390 includes asphalt, paraffin wax, and tar spills. One drum with several gallons of unknown liquid is also included. Some of the waste may be radioactive and/or hazardous/toxic.

CAU 395 includes concrete, oil, and asphalt spills. Several spills of unidentified materials are also included. Some of the waste may be radioactive and/or hazardous/toxic.

\section{Environmental Considerations}

W-1, Non-Rad Solid Waste: Any solid waste that may be generated from project activities will be disposed of at the NTS in a designated landfill.

W-2, Hazardous Waste: Several sites contain lead, PCB, or TPH-impacted and/or sanitary waste and soil. No other chemical hazards are known to exist. Personnel will be required to follow the safety procedures outlined in the Site Specific Health and Safety Plan and Job Hazard Analysis. Wastes will be disposed either on the NTS or offsite, depending on analysis results.

W-3, Low-level Rad Waste: Several sites are in a URMA, CA, or RMA. Radiologically impacted soil and debris in these areas may require disposal either at the Area 3 or Area 5 Radioactive Waste Management Sites.

W-4, Mixed Waste: Any waste which is classified as mixed waste will be disposed at the NTS in an approved mixed waste facility.

HM-1, Petroleum/Fuel (storage/use): Heavy equipment onsite will use petroleum fuel. No fuel will be stored onsite outside of the equipment. Absorbent pads will be used if equipment appears to be leaking petroleum.

HM-8. Beryllium: If any housekeeping site is determined to be in a legacy beryllium area, Industrial Hygiene will be contacted to provide guidance on how to minimize potential exposure 
to beryllium. This is in accordance with company procedure CM-0444.001-079, "Chronic Beryllium Disease Prevention".

A-2, Dust/ Particulate Matter: Some dust may be generated by excavation activities, but will be controlled as necessary by water spraying.

S-1, Environmental Restoration Site (CAU): These sites are included in the FFACO as CAU 286, 390, and 395 (See Project Description).

S-2, Excavation/Land Surface Disturbance: Equipment will travel off-road on previously disturbed areas. Equipment will also be used to help remove surface debris. Minor excavations may be required to remove stained soil at spill locations. All excavations will be performed under the appropriate permit.

S-9, Noise: Elevated noise levels may result from the operation of a backhoe and/or loader equipment. Personnel not directly involved with operation of this equipment will be kept back at least 15 feet while equipment is in use. The equipment operator will follow the instructions as directed in the Site Specific Health and Safety Plan.

S-10, Radiation Controlled Area: All CASs are in radiation controlled areas. All personnel onsite will have General Employee Radiological Training, at a minimum. Radiological Control Technicians will be onsite as required by Radcon. 
THIS PAGE INTENTIONALLY LEFT BLANK 
Closure Report - CAU 390

Section: Appendix D

Revision: 0

Date: October 2005

\section{APPENDIX D:}

\section{FFACO CORRESPONDENCE}


Closure Report - CAU 390

Section: Appendix D

Revision: 0

Date: October 2005

THIS PAGE INTENTIONALLY LEFT BLANK 
LEO M. DROZDOFF, Administrator (775) $687-4670$

Administration

Facsimile (775) 687-5856

Water Quality Planuing

Water Pollution Control

Facsimile (775) 687-4681

Mining Regulations and Reclamation Facsimile (775) 684.5259

Las Vegas Office

Facsimile (702) 486-2863

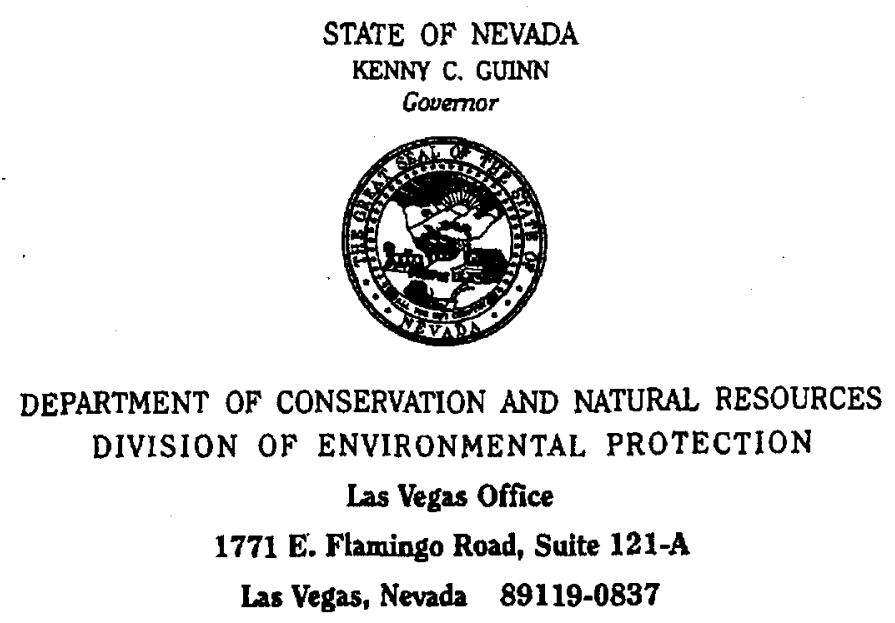

(702) $486-2850$

August 12, 2005
ALLEN BLAGGI, Director

- Air Pollution Control Air Quality Planning Facsimile (775) 687-6396

Waste Management Facsimile (775) 687.6396

Corrective Actions Facsimile (775) 687-8335

Federal Facilities Focsimile (702) \$86-2803

Webpage http:/ndep.nvisov

Ms. Janet Appenzeller-Wing, Acting Director

Environmental Restoration Division

National Nuclear Security Administration

Nevada Site Office

P.O. Box 98518

Las Vegas, NV 89193-8518

RE: $\quad$ Requests for Transfers of Corrective Action Sites (CASs) and a Corrective Action Unit (CAU), an Archive Request; and a Milestone Request - FFACO Meeting August 2005

Dear Ms. Appenzeller-Wing:

The Nevada Division of Environmental Protection, Bureau of Federal Facilities staff (NDEP) reviewed the information provided regarding the requests contained in the binder issued at the August 3, 2005 FFACO Meeting. Based on the information supplied, NDEP approves the following requests:

Transfer CAS 02-02-01, CAS 04-02-01, and CAS 23-02-05 from CAU 130 to CAU 4000.

Archive CAU 131 and change the description to Archived - Storage Tanks and Contaminated Materials, and move from Appendix II to Appendix $N$.

Transfer CAS 17-99-01, CAS 18-35-01, CAS 30-35-01, and CAS 18-19-01 from CAU 139 to CAU 5000.

Transfer CAS 10-22-19 from CAU 390 to $C A U 550$. 
Ms. Janet Appenzeller-Wing, Acting Director

Page 2

August 12, 2005

Change the CADD milestone for CAU 511 from 10/31/2005 to 1/31/2006.

Transfer CAS 09-09-45 from CAU 533 to CAU 177 and transfer CAS 09-09-41 from CAU 535 to $C A U 177$.

Transfer CAS 01-23-01 from CAU 537 to CAU 5000 and transfer CAS 11-99-01 from CAU 537 to $C A U 4000$.

Transfer CAS 18-01-02 from CAU 538 to CAU 5000.

Address any questions regarding this matter to either Ted Zaferatos at (702) 486-2856, Don Elle at (702) $486-2874$ or me at (702) $486-2857$.

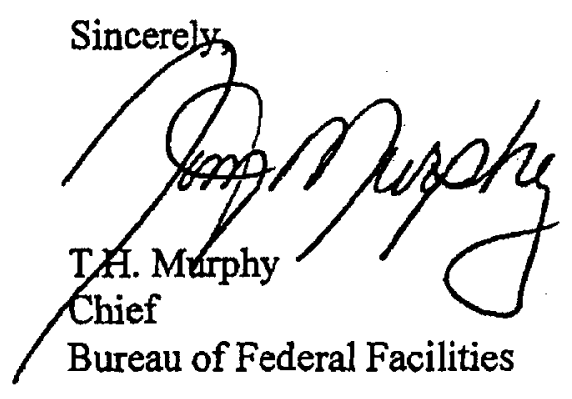

\section{DRE/TZ}

cc: Kenneth Hoar, ES\&HD, NNSANSO

Eric Shanholtz, Chief, DTRA

Patti Hall, TD, NNSA/NSO

Frank Di Sanza, WMD, NNSA/NSO

D.C. Loewer, DTRA/TDTN

Tiffany Lantow, DTRA/TDTNS

Wayne Griffin, SNJ/DTRA

Kevin Cabble, ERD, NNSA/NSO

Sabine Curtis, ERD, NNSANSSO 
Closure Report - CAU 390

Section: Library Distribution

Revision: 0

Date: October 2005

\section{LIBRARY DISTRIBUTION LIST}


Closure Report - CAU 390

Section: Library Distribution

Revision: 0

Date: October 2005

THIS PAGE INTENTIONALLY LEFT BLANK 


\section{LIBRARY DISTRIBUTION LIST}

U.S. Department of Energy

National Nuclear Security Administration

Nevada Site Office

Technical Library

P.O. Box 98518, M/S 505

Las Vegas, NV 89193-8518

U.S. Department of Energy

Office of Scientific and Technical Information

P.O. Box 62

Oak Ridge, TN 37831-0062

Southern Nevada Public Reading Facility

c/o Nuclear Testing Archive

P.O. Box $98521, \mathrm{M} / \mathrm{S} 400$

Las Vegas, NV 89193-8521

Manager, Northern Nevada FFACO

Public Reading Facility

c/o Nevada State Library \& Archives

Carson City, NV 89701-4285
1 (Uncontrolled)

1 (Uncontrolled, electronic copy)

2 (Uncontrolled, electronic copies)

1 (Uncontrolled, electronic copy) 
Closure Report - CAU 390

Section: Library Distribution

Revision: 0

Date: October 2005

THIS PAGE INTENTIONALLY LEFT BLANK 